\title{
Antagonistic effects of some commonly used herbs on the efficacy of Artemisinin derivatives in the treatment of malaria in experimental mice
}

\author{
O. A. Idowu', A. S. Babalola ${ }^{1 *}$ (D) and J. Olukunle
}

\begin{abstract}
Background: The use of herbs in combination with drugs in treatment of malaria is increasing, and this necessitated research on the possible antagonistic, additive, potentiation or synergistic properties of commonly used plants with standard drugs in treatment of malaria. In this study, extracts of Morindamorindiodes (Mm) root, Morindalucida (ML) leaf and Vernonia amygdalina (Va) leaf were combined with artesunate (Ar) and assessed for anti-malarial activities against established Plasmodium berghei NK65 infection in 45 experimental mice randomly distributed into 9 groups and treated at a graded dose of $100 \mathrm{mg} / \mathrm{kg}$ for the herbs and herbs-drugs combination, while chloroquine and artesunate was administered at $10 \mathrm{mg} / \mathrm{kg}$
\end{abstract}

Results: At the end the sixth day, Mm root extract, ML and Va leaf extract reduced parasitaemia by $86.83 \%, 84.20 \%$ and $48.10 \%$, respectively $(p<0.05)$. A total parasite clearance (100\% chemosuppression) was observed in the group treated with artesunate and chloroquine. However, the combination of each extracts of M. lucida, M. morindiodes and $V$. amygdalina with artesunate significantly reduced the chemosuppression to $89.93 \%, 89.43 \%$ and $86.93 \%$, respectively.

Conclusion: This study showed that though the extracts of Morinda morindiodes and Morinda lucida possess convincing antiplasmodial effect when administered singly, the combination of these extracts with artesunate could not produce total parasite clearance. There is need to enlighten the public on the possible setback associated with combined use of antimalarial plants with antimalaria drugs.

Keywords: Malaria, Treatment, Plasmodium, Herbs, Artesunate, Antagonist

\section{Background}

Malaria, a parasitic disease caused by protozoans of the genus Plasmodium, remains the world most devastating human parasitic infection (WHO 2013, 2020). Antimalaria drugs have been utilized in diverse ways to prevent or treat malaria infections in malaria endemic areas for many years. The issue of resistance of malaria

\footnotetext{
*Correspondence: ayodelebabalola2011@gmail.com

1 Malaria Research Unit, Department of Pure and Applied Zoology,

Federal University of Agriculture, Abeokuta, Nigeria

Full list of author information is available at the end of the article
}

parasite to anti-malaria drugs has been a lot of concern recently (WHO 2015; Ouji et al. 2018). As a result, researches are ongoing with aims of discovering more effective agents against the parasites. Currently, there are reports of parasite resistance to the currently developed Artemisinin combination therapy in some regions of Sub-Saharan Africa (WHO 2015; Ouji et al. 2018).

In recent times, natural products of plant sources have been given a lot of consideration as the main source of new, safer and more effective bioactive compounds with medicinal properties (Dike et al. 2012; Afolabi and Abejide 2020). Studies have documented over 1200 
plant species from 160 families used in the treatment of malaria or fever (Wilcox and Bodeker 2001). In fact, it is believed strongly that malaria would have destroyed Africa, if the herbs used to treat malaria by our ancestors were not effective. In Nigeria, malaria has become a household name, and the use of herbs to treat its symptoms is well established. A study revealed that different tribes in Nigeria maintain some sort of traditional medicine practitioner for treatment of various diseases including malaria (Ezekwesili and Okaka 2019). Furthermore, surveys conducted in different parts of Nigeria revealed many plants that had been identified by users to be potent against malaria (Nwachukwu et al. 2010; Idowu et al. 2010; Oludele and Olufunso 2018).

Vernonia amygdalina (bitter-leaf commonly found in West and Central African countries and Morinda lucida commonly found in northern and southern Nigeria, Fernadopo and over the Congo basin (Keay 1989) have been proven to have anti-plasmodial or anti-malarial activities against drug sensitive Plasmodium berghei in mice (Abosi and Raseroke 2003; Bello et al. 2009; Ebiloma et al. 2011; Paula et al. 2011; Lawal et al. 2012; Afolabi and Abejide 2020). A recent study has demonstrated that Morinda lucida possesses antimalarial properties attributed to anthraquinones (Idowu et al. 2010). The stem bark extract as well as the aqueous leaf extract of M. lucida has been reported to have chemosuppression properties ranging between $70 \%$ to $96.4 \%$, respectively (Obih et al. 1985; Ebiloma et al. 2011; Afolabi and Abejide 2020) in $P$. berghei infected mice.

A considerable reputation has been given to M. morindiodes (Rubiaceae) in traditional medicine in some African countries. Its use against malaria, diarrhoea, amoebiasis, gonorrhoea and rheumatic pains is regular (Kambu 1990; Bashir et al. 2015). The root extract of $M$. morindiodes has been reported to have antiplasmodial properties with $70 \%$ chemosuppression in P. berghei infected mice (Soniran et al. 2011).

The increasing use of the herbal medicine requires concern about interactions between herbs and conventional drugs and also the regulation of the herbal medicines (WHO 2013). Herbal usage is often combined with western pharmaceuticals without regards for any interaction between them. This could lead to decreased efficacy or increased toxicity (Cohen and Ernst 2010). The interaction between herbs and standard drugs may occur in many ways including; decrease or increase of the bioavailability of the drugs, antagonistic or synergistic with drugs, enhancement or inhibition of adverse effects etc. (Scott et al. 2014).

Herb-drug interactions occur but are underresearched. Based on these facts, there is a need to investigate the interactions between these plants and drugs.
These plants are among the most frequently used plants by healers and herbalists in Nigeria against malaria. Studying herb-drugs interactions in human is faced with ethical challenges; hence, animal models are used as substitutes to explain human related phenomena. Therefore, this study was conducted to determine the possible antagonistic effects of some commonly used herbs on the efficacy of Artemisinin derivatives in the treatment of malaria in experimental mice.

\section{Methods \\ Plant collection, identification and extraction}

Fresh leaves of M. lucida, V. amygdalina and roots of $M$. morindiodes were collected from locations around Odeda Local Government, Abeokuta. Permission to collect the plants was granted by the state Ministry of Forestry and later by the owners of land where the plants were located. Visual identification and authentication were carefully done by a plant taxonomist Dr. Ekundayo of the Forestry Research Institute of Nigeria (FRIN).

\section{Preparation of crude extract}

The plant parts were washed, dried at room temperature $\left(28 \pm 2^{\circ} \mathrm{C}\right)$ and then pulverized using plant grinder. These were soaked separately in distilled water for $24 \mathrm{~h}$ and later filtered. The filtrates were afterward evaporated to dryness over water bath at $35^{\circ} \mathrm{C}$ for further use (Idowu et al. 2014).

\section{Parasites}

Sample of $P$. berghei (NK-65), obtained from National Institute of Medical Research (NIMR), Lagos, Nigeria, was used for the research to evaluate the anti-malarial activity of the plant materials used in this study.

\section{Source of animals}

A total of 45 (sample size was determined according to the resource equation formulae my Charan and Kanthariamale 2013) BALB/c mice (each weighing between 23.0 and $23.2 \mathrm{~g}$ ) with mean weight of $23.2 \pm 0.2 \mathrm{~g}$ and same physiological age commercially obtained from Nigerian Institute of Medical Research (NIMR), Yaba, were used for this study. The mice were free of pathogens and have not been used for any initial experiment.

\section{Animal housing and husbandry}

The mice were kept in plastic cages which contained dried wood shavings as beddings at room temperature $\left(28 \pm 2^{\circ} \mathrm{C}\right)$ and were fed with standard ration (Vital Feeds Limited, Ibadan) and clean water in the animal house. The mice were kept at $12 \mathrm{~h} \mathrm{light}$ and dark cycle. 


\section{Experimental design}

A total of 45 mice (each weighing between 23.0 and $23.2 \mathrm{~g})$ were randomly divided into 9 groups. Six out of the nine groups were treated with the extracts (singly and in combination with artesunate) using oral administration with a single dose per day. A dosage of $100 \mathrm{mg} / \mathrm{kg}$ body weight was administered to each mouse for treatment with single plant extract. The untreated group served as the negative control, while the group treated with artesunate and chloroquine at a dose of $10 \mathrm{mg} / \mathrm{kg}$ body weight served as the positive control for the experiment. Groups 1-3 were treated with the plant extracts at $100 \mathrm{mg} / \mathrm{kg}$, while groups $4-6$ were treated with combination of the plant extracts and artesunate. The treatment continued daily for six consecutive days. The experimental groups are presented in Table 1. At the end of experiment, the mice were kept for further studies.

\section{Inoculation of experimental mice}

Malaria parasite inoculums were prepared by collecting blood samples from donor mouse. The blood

\section{Treatment of infected mice}

Leaves extracts of $M$. lucida (Leaves), M. morindiodes (Root) and $V$. amygdalina (Leaves) and their various combinations with artesunates were administered to the mice orally with the aid of an oral cannula at $100 \mathrm{mg} / \mathrm{kg}$ bodyweight. Single administration with chloroquine and artesunate was administered at $10 \mathrm{mg} / \mathrm{kg}$ bodyweight, respectively.

\section{Measurement of experimental outcomes \\ Estimation of percentage chemosuppression}

Each day, blood samples were taken from the caudal vein of each mouse on a clean glass slide; thin films were prepared and stained with $10 \%$ Giemsa solution. The parasitaemia was estimated by careful examination of the well-stained thin blood film. Parasitaemia was determined by dividing the number of parasitized red blood by the total number of red blood cells and then multiplied by 100 to express it as a percentage.

Percentage malaria parasitaemia (\%) and Day 6 chemosuppression (\%) were determined using the formula below:

Percentage malaria parasitaemia $(\%)=\frac{\text { Number of parasitized RBC }}{\text { Total number of } \mathrm{RBC} \text { counted }} \times 100$

Day 6 Malaria chemosuppression $=\frac{\text { MP of untreated at day } 6-\text { MP of treated at day } 6}{\text { MP of untreated at day } 6} \times 100$

collected from the donor mouse was then diluted with normal saline such that $0.1 \mathrm{ml}$ contained $10^{4}$ of the parasite.

Forty-five (45) mice were divided into nine (9) groups of five mice each; all the mice were infected with the parasites by inoculating them intraperitonially with $0.1 \mathrm{ml}$ of the prepared blood solution. where MP is the percentage malaria parasitaemia.

\section{Statistical analysis}

Raw data obtained from the laboratory were analysed using one-way analysis of variance (ANOVA) to compare means across groups using Statistical Product and Service Solution (SPSS), version 21.0 (Chicago, IL). The data

Table 1 Experimental plans for test animals and control

\begin{tabular}{|c|c|c|}
\hline Groups & Experimental plan & Remarks \\
\hline $1,2,3$ & $\begin{array}{l}\text { Were infected with Plasmodium berghei and administered with } 100 \mathrm{mg} / \mathrm{kg} \text { body weight of Morinda lucida, } \\
\text { Morinda morindiodes and Vernonia amygdalina plant extracts, respectively, for } 6 \text { consecutive days }\end{array}$ & Treatment \\
\hline $4,5,6$ & $\begin{array}{l}\text { Were infected with Plasmodium berghei and administered with } 100 \mathrm{mg} / \mathrm{kg} \text { body weight of combination of } \\
\text { Morinda lucida, Morinda morindiodes and Vernonia amygdalina plant extracts with artesunate, respec- } \\
\text { tively, for } 6 \text { consecutive days }\end{array}$ & Herb-drug combined treatment \\
\hline 7,8 & $\begin{array}{l}\text { Were infected with Plasmodium berghei and administered with } 10 \mathrm{mg} / \mathrm{kg} \text { body weight of artesunate and } \\
\text { chloroquine for } 6 \text { consecutive days }\end{array}$ & Drug treatment control \\
\hline 9 & Were infected but not Treated & Untreated control \\
\hline
\end{tabular}


Table 2 Mean percentage parasitaemia of mice treated with single therapy

\begin{tabular}{|c|c|c|c|c|c|c|}
\hline Treatment Grps & Day1 & Day2 & Day3 & Day4 & Day5 & Day6 \\
\hline M. morindiodes & $23.25 \pm 0.29^{a}$ & $21.83 \pm 0.29^{c}$ & $20.38 \pm 0.29^{c}$ & $11.72 \pm 0.13^{c}$ & $10.25 \pm 0.04^{b}$ & $4.21 \pm 0.11^{b}$ \\
\hline M. lucida & $27.73 \pm 0.04^{d}$ & $26.73 \pm 0.04^{d}$ & $24.98 \pm 0.04^{d}$ & $18.18 \pm 0.11^{d}$ & $10.99 \pm 0.56^{b}$ & $6.99 \pm 0.02^{c}$ \\
\hline V. amygdalina & $29.07 \pm 0.02^{e}$ & $28.20 \pm 0.18^{e}$ & $23.81 \pm 0.33^{d}$ & $19.15 \pm 0.60^{e}$ & $18.34 \pm 0.67^{c}$ & $17.38 \pm 0.60^{d}$ \\
\hline Artesunate & $26.38 \pm 0.13^{c}$ & $20.76 \pm 0.13^{b}$ & $10.05 \pm 0.13^{b}$ & $3.26 \pm 0.07^{b}$ & $0.00 \pm 0.00^{\mathrm{a}}$ & $0.00 \pm 0.00^{a}$ \\
\hline Chloroquine & $25.75 \pm 0.13^{b}$ & $17.48 \pm 0.13^{a}$ & $8.56 \pm 0.13^{a}$ & $2.5 \pm 0.07^{a}$ & $0.00 \pm 0.00^{a}$ & $0.00 \pm 0.00^{a}$ \\
\hline Untreated & $29.88 \pm 0.13^{f}$ & $30.43 \pm 0.13^{f}$ & $30.71 \pm 0.13^{e}$ & $31.14 \pm 0.00^{f}$ & $33.05 \pm 0.00^{d}$ & $32.67 \pm 0.07^{e}$ \\
\hline
\end{tabular}

Values were expressed as mean \pm standard deviation (SD). Values with different superscripts (Alphabets) in a column are significantly different ( $p<0.05$ ) from each other. This implies that for each day, values with superscript a are the least value, followed by b then $c$, $d$ e to $f$ (highest). For example, at day 1 , the lowest values for percentage parasitaemia were recorded in mice treated with M. morindiodes followed by that of chloroquine, while the highest parasitaemia was in untreated mice. These differences are statistically significant (all the values did not have similar superscript). At days 5 and 6 , mice treated with artesunate and chloroquine have the least values for parasitaemia and both the same superscripts (a). This means they are not significantly different from one another

Mean values were from five mice observed in each group

were first checked for normality of distribution using normality Kolmogorov-Smirnov and Shapiro-Wilk tests. The results were presented as mean \pm standard deviation (SD) in tables. Mean values with $p<0.05$ were considered significant.

\section{Results}

A steady and consistent reduction in parasitaemia was observed in mice treated with all plant extracts from day 1 to 6 . However, the level of chemosuppression varies with each plant extracts (Table 2).

The root extract of $M$. morindiodes was observed to produce a high reduction in parasitaemia (Table 2) with chemosuppression of $86.83 \%$ on day 6 (Fig. 1). Furthermore, the root extract of $M$. morindiodes recorded a significantly higher day $1(p<0.05)$ chemosuppression than the positive control (artesunate) (Fig. 1). There was a close margin between the chemosuppression demonstrated by M. morindiodes and artesunate even at day 2 of treatment. Though chemosuppression increased significantly in groups treated with $M$. morindiodes in the subsequent days, a wide gap in chemosuppression was observed between the artesunate group and M. morindiodes group (Fig. 1).

Chemosuppression of Morinda lucida on day 1 was $6.87 \%$ compared with $21.45 \%$ recorded in Morinda morindiodes $(p<0.05)$. The wide gap in chemosuppression between $M$. morindiodes and $M$. lucida continued for 4 days. As at the $5^{\text {th }}$ day of treatment, there was no significant difference between the chemosuppression demonstrated by both plants (Fig. 1).

Vernonia amygdalina produced a significantly $(p<0.05)$ lower chemosuppression than M. morindiodes and M. lucida on day 6 of the experiment. The

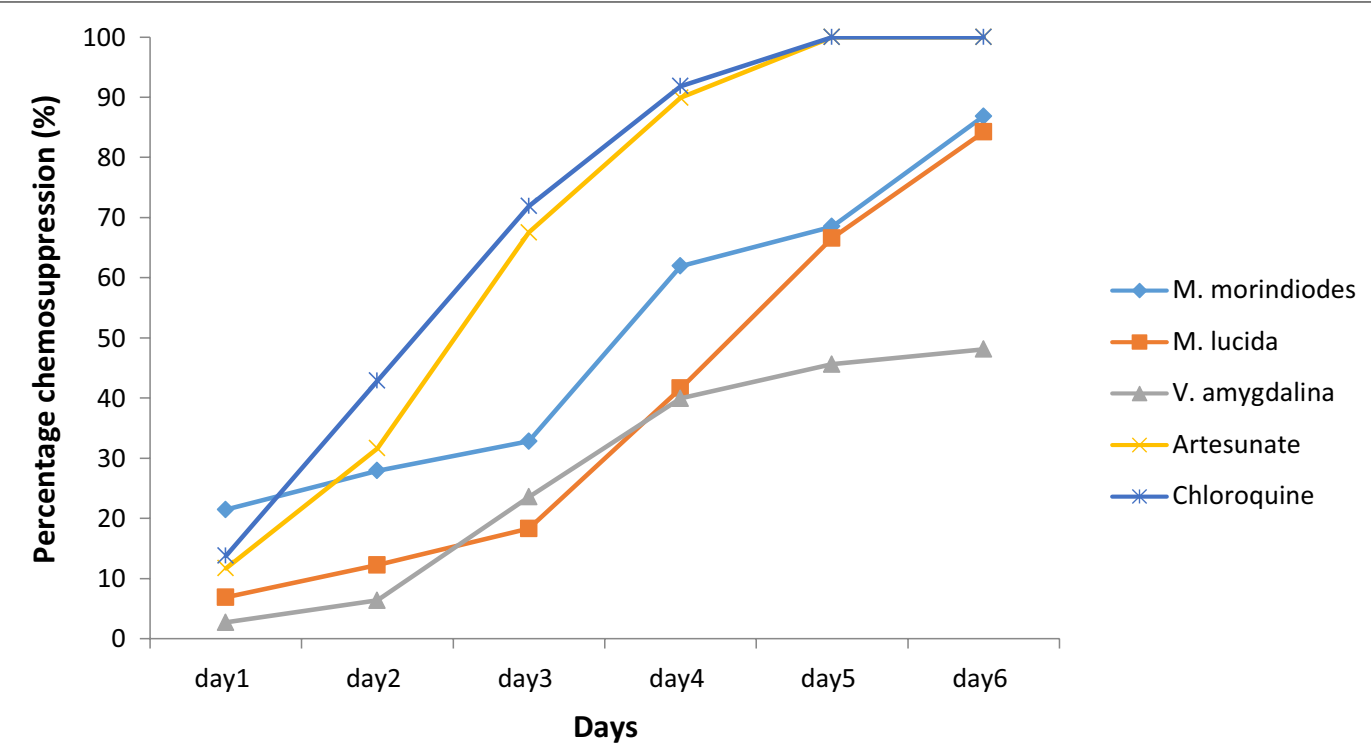

Fig. 1 Percentage chemosuppression of parasitaemia of infected mice treated with single therapy 
differences observed in chemosuppression of M. morindiodes and M. lucida was observed to be statistically $(p<0.05)$ significant throughout the experiments. All the plant extracts show significant differences $(p<0.05)$ when compared with the untreated group (Table 2 ).

\section{Combined treatment (Herb vs. artesunate)}

A total parasite clearance was observed in mice treated among the mice treated with chloroquine and artesunate alone (Table 3). However, the combination of each extracts of M. lucida, Morinda morindiodes and $V$. amygdalina with artesunate significantly reduced the chemosuppression to $89.93 \%, 89.43 \%$ and $86.93 \%$, respectively $(p<0.05)$ when compared with the control groups treated with artesunate and chloroquine alone (Fig. 2).

The group treated with combination of artesunate with $V$. amygdalina $(A r+V a)$ recorded the lowest day 1 chemosuppression when compared with other combinations $(p<0.05)$. However, high increase in chemosuppression was observed during the subsequent days of treatment. As at the $5^{\text {th }}$ day of treatment, there was a close gap in chemosuppression between all the combined treatment groups (Fig. 2).

Table 3 Mean percentage parasitaemia of mice treated with combined therapy

\begin{tabular}{llllrrr}
\hline Treatment Grps & Day1 & Day2 & Day3 & Day4 & Day5 & Day6 \\
\hline Artesunate + Va & $29.18 \pm 0.13^{\mathrm{e}}$ & $29.01 \pm 0.13^{\mathrm{e}}$ & $26.9 \pm 0.17^{\mathrm{e}}$ & $11.35 \pm 0.07^{\mathrm{e}}$ & $5.35 \pm 0.7^{\mathrm{d}}$ & $4.19 \pm 0.07^{\mathrm{d}}$ \\
Artesunate + Mm & $25.91 \pm 0.13^{\mathrm{c}}$ & $26.03 \pm 0.13^{\mathrm{d}}$ & $17.33 \pm 0.13^{\mathrm{d}}$ & $9.36 \pm 0.07^{\mathrm{d}}$ & $3.81 \pm 0.07^{\mathrm{b}}$ & $3.59 \pm 0.07^{\mathrm{c}}$ \\
Artesunate + Ml & $23.13 \pm 0.13^{\mathrm{a}}$ & $23.53 \pm 0.13^{\mathrm{c}}$ & $13.78 \pm 0.13^{\mathrm{c}}$ & $8.03 \pm 0.07^{\mathrm{c}}$ & $4.44 \pm 0.07^{\mathrm{c}}$ & $3.37 \pm 0.07^{\mathrm{b}}$ \\
Artesunate & $26.38 \pm 0.13^{\mathrm{d}}$ & $20.76 \pm 0.13^{\mathrm{b}}$ & $10.05 \pm 0.13^{\mathrm{b}}$ & $3.26 \pm 0.07^{\mathrm{b}}$ & $0.00 \pm 0.00^{\mathrm{a}}$ & $0.00 \pm 0.00^{\mathrm{a}}$ \\
Chloroquine & $25.75 \pm 0.13^{\mathrm{b}}$ & $17.48 \pm 0.13^{\mathrm{a}}$ & $8.56 \pm 0.13^{\mathrm{a}}$ & $2.5 \pm 0.07^{\mathrm{a}}$ & $0.00 \pm 0.00^{\mathrm{a}}$ & $0.00 \pm 0.00^{\mathrm{a}}$ \\
Untreated & $29.88 \pm 0.13^{\mathrm{f}}$ & $30.43 \pm 0.13^{\mathrm{f}}$ & $30.71 \pm 0.13^{\mathrm{f}}$ & $31.14 \pm 0.00^{\mathrm{f}}$ & $33.05 \pm 0.00^{\mathrm{e}}$ & $32.67 \pm 0.03^{\mathrm{e}}$ \\
\hline
\end{tabular}

Values were expressed as mean \pm standard deviation (SD). Values with different superscripts (Alphabets) in a column are significantly different ( $p<0.05$ ) from each other. This implies that for each day, values with superscript (a) are the least value, followed by b then c, $d$ e to f (highest). For example, at day 1 , the lowest values for percentage parasitaemia were recorded in mice treated with artesunate + Ml followed by that of chloroquine while the highest parasitaemia was in untreated mice. These differences are statistically significant (all the values did not have similar superscript). At days 5 and 6 , mice treated with artesunate and chloroquine have the least values for parasitaemia and both the same superscripts (a). This means they are not significantly different from one another. The opposite goes for mice treated with (artesunate $+\mathrm{Mm}$ ) and (artesunate $+\mathrm{Ml}$ ) at day 6 . The former was significantly higher than the latter $(p<0.05)$ due to the fact that the two values share different superscripts (b and c)

Mean values were from five mice observed in each group
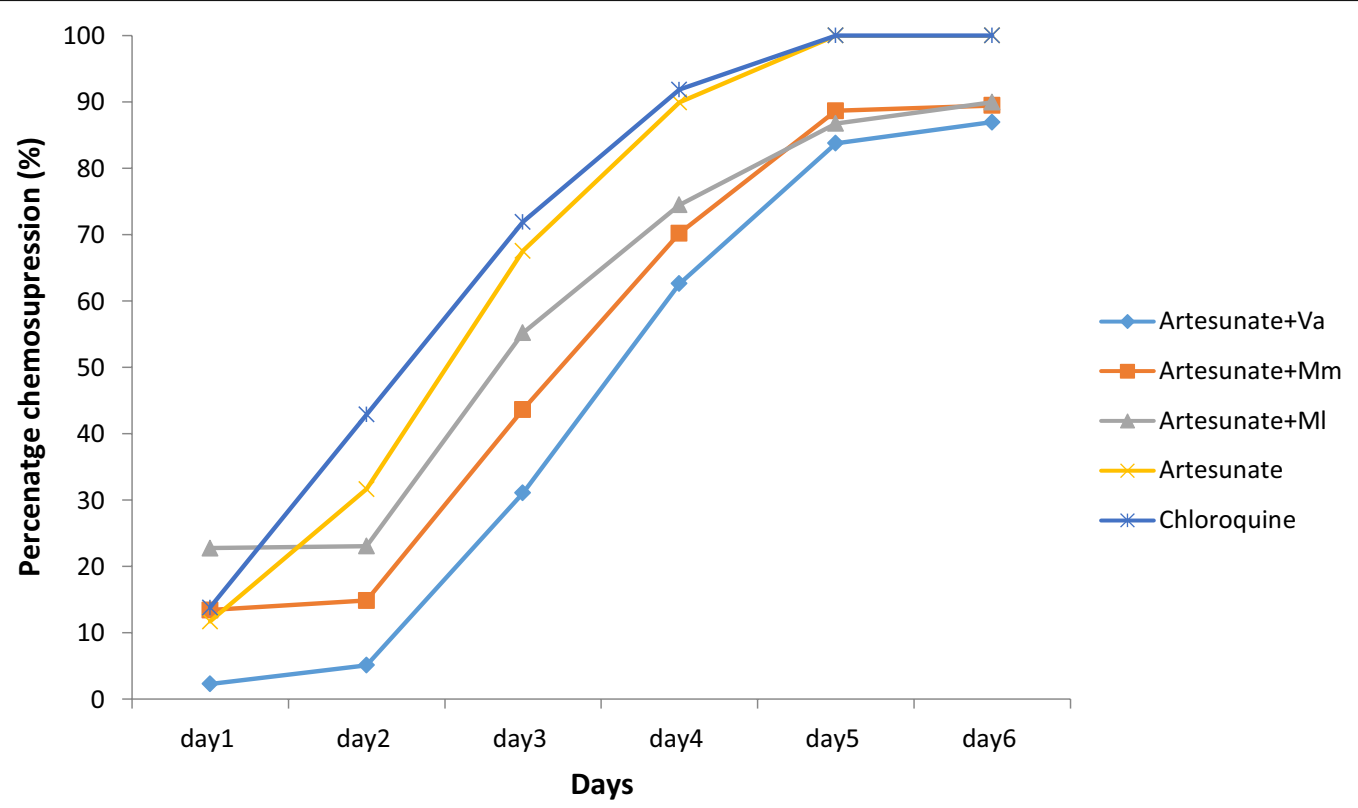

Fig. 2 Percentage chemosuppression of parasitaemia of infected mice treated with combined therapy 
Though the combination of M. lucida plant extracts and artesunate produced the highest day 1 chemosuppression compared with the positive control (artesunate) (Fig. 2), its combination with artesunate reduced the efficacy of artesunate during this study.

\section{Discussion}

In this study, the anti-plasmodial effects of three plant extracts in both single therapy and combined therapy (herb-drugs) was observed in a six day treatment of $P$. berghei infected mice.

Morinda morindiodes initiated a very early chemosuppression than artesunate and other plant extracts when administered singly. (It recorded a significantly higher chemosuppression than artesunate on the first day of treatment.) However, it could not maintain the property when combined with artesunate. Studies have shown that $M$. morindiodes is able to act faster as an anti-plasmodial agent when administered singly (Idowu et al. 2014). This finding is in conformity with other report from Nigeria that recorded similar performance in water extract of the root of Morindamorindiodes in which a significant decrease in parasitaemia (70\%) was reported in comparison with the activities of other plant parts in P. berghei infected mice (Soniran et al. 2011).

Leaf extract of M. lucida in this study demonstrated a chemosuppression of $84.2 \%$ in a six-day treatment. This is in keep with the findings of Ebiloma et al. (2011), who reported up to $85.05 \%$ chemosuppression in vivo antiplasmodial activity of aqueous leaf extract of $M$. lucida carried out in P. berghei NK-65 parasitized mice.

A more recent study on antiplasmodial effect of crude extract of $M$. lucida root showed a chemosuppression of 56.3\% (Maimuna et al. 2013). The disparity observed with this current study could be as a result of the plant parts used. This could suggest that Leaf $M$. lucida may possess more antiplasmodial properties compared with other parts.

Alkaloids and flavonoid have been identified as the predominant secondary metabolite from the phytochemical screening of the aqueous leaf extract of $M$. lucida (Ebiloma et al. 2011). The high alkaloid and flavonoid contents could be linked to the observed antimalarial activity in the group treated with M. lucida. Previous works have also shown the antimalaria activity of alkaloids and flavonoids in plants (Balogun et al. 2009; Okokon et al. 2005).

Leaf extract of $V$. amygdalina demonstrated a percentage chemosuppression of $48.1 \%$ in a six-days treatment. Leaf extract of $V$. amygdalina assessed against $P$. berghei by Abosi and Raseroke (2003) produced 67\% suppression of parasitaemia. The huge difference in suppression rate observed in the mice treated with $V$. amygdalina in this study could be attributed to the dose-dependent nature of its crude extract (Abosi and Raseroke 2003; Njan et al. 2008; Paula et al. 2011). Majority of the studies that reported high suppression administered the plant extract at higher dose $(>200 \mathrm{mg} / \mathrm{kg}$ compared with $0.1 \mathrm{mg} / \mathrm{g}$ employed in this study).

The production of varieties of flavonoids and bitter sesquiterpene lactones has contributed to the bio activities of V. amygdalina (Favi et al. 2008). However, the taxonomy of $V$. amygdalina from different geographical area could be different, hence, possessing variable bio activities (Austin 2000). Thus, the low suppression of parasitaemia observed in the mice treated with Vernonia amygdalina compared with some other studies (Abosi and Raseroke 2003; Njan et al. 2008) could also be attributed to difference in geographical locations in which the plants were collected.

Viewing from the angle of herb-drug relationship, all the plant extracts reduce the efficacy of artesunate, implying a sort of an antagonistic effect. The standard drug (artesunate) produced the highest efficacy, when compared with the activities of the plant extracts. One reason is the fact that the plant extracts are in their crude forms with the active components not isolated and developed into active drugs (Adzu and Haruna 2007; Ebiloma et al. 2011; Idowu et al. 2014). On the other hand, this might be an indication that there is some level of antagonistic relationship between the plant extracts and artesunate in this study. This could be as a result of possible reduction in the bio-availability of artesunate in the host blood (Brinker et al. 1998) or the stimulation of enzyme activities to degrade the drug. The reduction in the efficacy of artesunate recorded in this study has implication for development of drug resistance (Watkins and Wosobo 1993). It has been reported that combination of herbs with western pharmaceuticals without regards for any interaction between them is a common phenomenon in malaria endemic areas (Idowu and Mafiana 2007; Uzor et al. 2020). One major limitation of this study is that the bioavailability of the drug was not accessed in the experimental mice. Hence, our future studies will the tailored toward that direction.

\section{Conclusion}

This study showed that though the extracts of Morinda morindiodes and Morinda lucida possess convincing antiplasmodial effect when administered singly, the combination of these extracts with artesunate could not produce total parasite clearance. There is need to enlighten the public on the possible setback associated with combined use of antimalarial plants with antimalaria drugs. 


\section{Abbreviations}

Mm: Morinda morindiodes; Ml: Morinda lucida; Va: Vernonia amygdalina; M. lucida: Morinda lucida; V. amygdalina: Vernonia amygdalina; M. morindodes: Morinda morindiodes; MP: Malaria parasitaemia; NIMR: Nigeria Institute of Medical Research.

\section{Acknowledgements}

Our appreciations go to Mrs. Adenubi of the Department of Veterinary physiology and pharmacology for the help rendered during the extraction of the plant extracts. We also want to appreciate Dr. Aina of NIMR for his assistance in providing the parasite.

\section{Authors' contributions}

Author IOA conceptualized this research. Authors BAS and IOA designed the research protocol and methodology. Authors BAS and IOA carried out the field work. Author OJ provided studies and other technical inputs. Author BAS did the statistical analysis and developed the manuscript. All the authors read, corrected and approved the final manuscript.

\section{Funding}

This research did not receive any specific grant from funding agencies in the public, commercial or not-for-profit sectors.

\section{Availability of data and materials}

The datasets generated during and/or analysed during the current study are not publicly available due [General agreement among the authors] but are available from the corresponding author on reasonable request.

\section{Ethics approval and consent to participate}

Nigeria Institute of Medical Research gave approval to use the animals for this study. The ethics and consent concerning the use of mice for this research were approved by the Department of Biological Sciences, University of Agriculture, Abeokuta, Nigeria, with Reference number UG/2007/0920. Experiments were performed in accordance with the Guide of the Care and Use of Laboratory Animals of the National Institutes of Health.

\section{Consent for publication}

Not applicable.

\section{Competing interests}

The authors declare that they have no competing interests.

\section{Author details}

${ }^{1}$ Malaria Research Unit, Department of Pure and Applied Zoology, Federal University of Agriculture, Abeokuta, Nigeria. ${ }^{2}$ Pharmacology Research Unit, Department of Veterinary Physiology and Pharmacology, Federal University of Agriculture, Abeokuta, Nigeria.

Received: 30 July 2020 Accepted: 27 September 2020

Published online: 09 October 2020

\section{References}

Abosi AO, Raseroke BH (2003) In vivo antimalarial activity of Vernonia amygdalina. Br J Biomed Sci 60(2):89-91

Adzu B, Haruna A (2007) Studies on the use of Zizyphus Spina-Christi against pain in rats and mice. Afr J Biotech 6:1317-1324

Afolabi OJ, Abejide AE (2020) Antiplasmodial activities of Morinda lucida (Benth) and Alstonia boonei (De wild) in mice infected with Plasmodium berghei. Bull Natl Res Centre 44:85. https://doi.org/10.1186/s42269-020$00342-8$

Austin DF (2000) Book reviews. Econ Bot 54:234-245

Balogun EA, Adebayo JO, Zailani AH, Kolawole OM, Ademowo OG (2009) Activity of ethanolic extract of Clerodendrum violaceum leaves against Plasmodium berghei in mice. Agric Biol J North Am 2009(1):307-312

Bashir L, Oluwatosin KS, Adamu YK, Ali AJ, Maimuna BU, Eustace BB, Blessing UA (2015) Potential antimalarials from African natural products: a review.
J Complement Med Res 4(4):318-343. https://doi.org/10.5455/jice.20150 928102856

Bello IS, Oduola T, Adeosun OG, Omisore NO, Raheem GO, Ademosun AA (2009) Evaluation of antimalarial activity of various fractions of Morindalucida leaf extract and Alstoniaboonei stem bark. Glob J Pharmacol 3(3):163-165

Brinker F (1998). Herb contraindications and drug interactions. Eclectic Institute Publishers, 46-47

Charan J, Kantharia ND (2013) How to calculate sample size in animal studies? J Pharmacol Pharmacotherap 4(4):303-306. https://doi. org/10.4103/0976-500X.119726

Cohen B, Ernst D (2010) Safety of herbal supplements: a guide for cardiologists. Cardiovasc Therapy 28(4):246-253

Dike IP, Obembe OO, Adebiyi FE (2012) Ethnobotanical survey for potential anti-malarial plants in south-western Nigeria. J Ethnopharmacol 144(3):618-626

Ebiloma GU, Omale J, Aminu RO (2011) Suppressive, curative and prophylactic potentials of Morindalucida(Benth) against erythrocytic stage of mice infective Plasmodium berghei NK-65. Br J Appl Sci Technol 1(3):131-140

Ezekwesili JO, Okaka ANC (2019) Herbal medicines in African traditional medicine. Herbal Med 19:191-219. https://doi.org/10.5772/intechopen .80348

Favi F, Cantrell CL, Mebrahtu T, Kraemer ME (2008) Leaf peltate grandular trichomes of $V$. amygdalina spp. Galamensisvarethiopicagilbart: development, ultrastructure and chemical composition. Int J Plant Sci 169:605-614

Idowu OA, Mafiana CF (2007) Malaria in pregnancy: Knowledge, attitude and practices of pregnant women in Abeokuta Nigeria. Nigeria J Parasitol 28(2):61-64

Idowu OA, Babalola AS, Adenubi OT, Olukunle JO (2014) Antiplasmodial activities of combined extracts of Morinda morindiodes, Morinda lucida and Vernonia amygdalina in Plasmodium berghei infected mice. Zoologist 11:40-45

Idowu OA, Soniran OT, Ajana O, Aworinde DO (2010) Ethnobotanical survey antimalarial plants used in Ogun State, South West. Nigeria. Afr J Pharm Pharmacolo 4(2):55-60

Kambu, K. (1990). Elements de phytotherapic compare. Plants Medicinales Africanus, CRP-Kinshaska, 20-22

Keay, R.W.J. (1989). Trees of Nigeria. Oxford Science Publishers, pp. 418-437.

Lawal HO, Etatuvie SO, Fawehinmi AB (2012) Ethnomedicinal and pharmacological properties of Morindalucida. J Nat Prod 5(2012):93-99

Maimuna BU, Emmanuel OO, Josephine YI, Oluwakanyinsola AS, Adeniyi YT, Ibrahim MH (2013). Antiplasmodial efficacy of methanolic root and leaf extracts of Morindalucida. J Nat Res 3(2): ISSN 2224-3186

Njan AA, Adzu B, Agaba AG, Byarugaba D, Diaz-Llera S, Bangsberg DR (2008) The analgesic and antiplasmodial activities and toxicology of Vernonia amygdalina. J Med Food 11:574-581

Nwachukwu CU, Umeh CN, Kalu IG, Okere S, Nwoko MC (2010) Identification and traditional uses of some common medicinal plants in Ezinihitte Mbaise L.G.A., of Imo State, Nigeria. Report Opinion 2(6):1-8

Obih PO, Makinde JM, Laoye JV (1985) Investigation of various extracts of Morindalucida for antimalarial actions on Plasmodium berghei in mice. Afr J Med Sci 14:45-49

Okokon JE, Ofodum KC, Ajibesin KK (2005) Pharmacological screening and evaluation of antiplasmodial activity of Croton zambesicus against Plasmodium berghei berghei infection in mice. Indian J Pharmacol $37: 243-246$

Oludele JO, Olufunso 00 (2018) Toxicology of solvent extract and fractions of Alstonia boonei (DC) wild stem bark in rats. Laboratories for Biomembrane Research and Biotechnology, Department of Biochemistry, Faculty of Basic Medical Sciences, College of Medicine, University of Ibadan. J Herbmed Pharmacol 7(3):129-135

Ouji M, Augereau JM, Paloque L, Benoit-Vical F (2018) Plasmodium falciparum resistance to artemisinin-based combination therapies: a sword of Damocles in the path toward malaria elimination. Parasite 25:24. https:// doi.org/10.1051/parasite/2018021

Paula M, William C, Paschal E, Peter S (2011) In vitroand in vivo antiplasmodial activities of extracts ofCymbopogoncitratus Staph and Vernonia amygdalinaDelile leaves. J Nat Prod 4(2011):0974-5211 
Scott JB, Aneesh AA, Yvonne SL, Swati N, Mary FP (2014) Herb-Drug Interactions: challenges and opportunities for improved predictions. Drug Metab Dispos 42(3):301-317

Soniran OT, Idowu OA, Idowu AB, Ajana O (2011) Evaluation of in vivo Antiplasmodial Activities ofextracts of Morindamorindiodes (Bak.) in the treatment of malaria in Ogun State. Int J Biomed Health Sci 7(4): 299-306

Uzor PF, Prasasty VD, Agubata CO (2020) Natural products as sources of antimalarial drugs. Evid-Based Complementary Alternat Med 20:1-2. https:// doi.org/10.1155/2020/9385125

Watkins WM, Wosobo M (1993) Treatment of Plasmodium falciparum malaria with pyrimethamine-sulfadoxine: selective pressure for resistance is a function of long elimination half-life. Trans R Soc Trop Med Hyg 87:75-78 WHO (2013) Water-related diseases. World Health Organization, Geneva, Switzerland. Retrieved from: https://www.who.int/water_sanitation_healt h/diseases/malaria/en/
WHO (2015) Control of residual malaria parasite transmission. Global malaria programme, 2015

WHO (2020) Malaria eradication: benefits, future scenarios and feasibility: a report of the Strategic Advisory Group on Malaria Eradication. World Health Organization, Geneva, Switzerland. Retrieved from: https://www who.int/publications/i/item/malaria-eradication-benefits-future-scena rios-feasibility

Wilcox ML, Bodeker G (2001) Traditional herbal medicines for malaria. BMJ 329:1156-1159

\section{Publisher's Note}

Springer Nature remains neutral with regard to jurisdictional claims in published maps and institutional affiliations.

\section{Submit your manuscript to a SpringerOpen ${ }^{\odot}$ journal and benefit from:}

- Convenient online submission

- Rigorous peer review

- Open access: articles freely available online

- High visibility within the field

- Retaining the copyright to your article

Submit your next manuscript at $\boldsymbol{\nabla}$ springeropen.com 